\title{
Lack of Induction of Direct and Cross Tolerance To Salts and Organic Acids in Enterotoxigenic Staphylococcus aureus After Habituation To Origanum Vulgare L. Essential Oil
}

Adassa Gama Tavares (I), Daniel Farias Marinho do Monte (I), Kataryne Árabe Rima de Oliveira (I), Tereza Cristina Rocha Moreira de Oliveira (II), Marciane Magnani (I), José Pinto de Siqueira Junior

(I), Evandro Leite de Souza (I)

(I) UFPB - Federal University of Paraiba (Cidade Universitária - João Pessoa - PB - Brasil CEP: 58051-900), (II) UEL - Londrina State University (Campus Universitário - Londrina - PR -

Brasil - CEP: 86057-970)

\section{Resumo}

The exposure of food-related bacteria to stressing factors during food processing can cause sublethal damage to bacterial cells and during the injury repair process these cells could acquire abilities to adapt to these stress-inducing agents, leading to impacts on food safety. Staphylococcus aureus is one of the most common causes of foodborne diseases worldwide, causing a intoxication through the ingestion of enterotoxins pre-formed in foods. This bacterium is capable of developing tolerance to heat, acidic $\mathrm{pH}$ and salts when exposed to sublethal stress conditions. The aim of this study was to assess the ability of enterotoxigenic S. aureus strains isolated from foods to develop direct- and cross-tolerance to sodium chloride $(\mathrm{NaCl})$, potassium chloride ( $\mathrm{KCl}$ ), lactic acid (LA) and acetic acid (AA) after habituation to Origanum vulgare L. essential oil (OVEO). Four strains (FRI-S-6; FRI-196-3; FRI-326; ATCC 13565) producing enterotoxins A, $\mathrm{B}, \mathrm{D}$ or $\mathrm{E}$ were used as test-organisms. The Minimum Inhibitory Concentration (MIC) to tested antimicrobial agents were determined by the microdilution method and the induction to direct- and cross-tolerance was

\footnotetext{
Referência:

Adassa Gama Tavares, Daniel Farias Marinho do Monte, Kataryne Árabe Rima de Oliveira, Tereza Cristina Rocha Moreira de Oliveira, Marciane Magnani, José Pinto de Siqueira Junior, Evandro Leite de Souza. Lack of Induction of Direct and Cross Tolerance To Salts and Organic Acids in Enterotoxigenic Staphylococcus aureus After Habituation To Origanum Vulgare L. Essential Oil. In: Anais do 12 Congresso Latinoamericano de Microbiologia e Higiene de Alimentos - MICROAL 2014 [= Blucher Food Science Proceedings, num.1, vol.1]. São Paulo: Editora Blucher, 2014.

DOI 10.5151/foodsci-microal-303
} 
evaluated after the exposure of strains to sublethal amounts ( $1 / 2$ MIC and $1 / 4$ MIC) of OVEO in Brain Heart Infusion Broth for 24, 48 and 72 hours, followed by new MIC determination. The induction of tolerance was assessed by comparing the MIC values before and after the habituation treatment. Control systems were assayed similarly. MIC values of OVEO ranged from 2.5 to $10 \mu \mathrm{L} \mathrm{mL}^{-1} ; \mathrm{NaCl}, \mathrm{KCl}, \mathrm{AA}$ and LA showed MIC values of $200 \mathrm{mg} \mathrm{mL}^{-1}, 300 \mathrm{mg} \mathrm{mL}^{-1}, 2.5 \mu \mathrm{L} \mathrm{mL}^{-1}$ and $10 \mu \mathrm{L} \mathrm{mL}^{-1}$, respectively, against all the assayed strains. The habituation of $\mathrm{S}$. aureus to $1 / 2$ MIC and $1 / 4$ MIC of OVEO did not induce direct tolerance or crosstolerance in the tested strains. Strains habituated to sublethal concentrations of OVEO maintained or increased the sensitivity to the tested stressing agents because the MIC values of OVEO, $\mathrm{NaCl}, \mathrm{KCl}$, LA and AA against the cells that were previously habituated to OVEO remained the same or decreased when compared with non-habituated cells. These data indicate that OVEO does not have an inductive effect on the acquisition of direct or cross-tolerance in the tested enterotoxigenic strains of $\mathrm{S}$. aureus to antimicrobial agents that are typically used in food industry.

Palavras-Chave: Adaptation, Oregano, Staphylococcus, Tolerance Agência de Fomento: 